\title{
Intergenerational Mobility, Human Capital Transmission and the Earnings of Second-Generation Immigrants in Sweden*
}

by

\author{
Mats Hammarstedt ${ }^{\mathrm{a}}$ and Mårten Palme ${ }^{\mathrm{b}}$
}

\begin{abstract}
We compare the intergenerational earnings mobility of immigrants with natives in Sweden. We find an overall convergence in average earnings between immigrants and natives. This convergence hides a divergence in average earnings between groups of immigrants with different ethnic origins. We find that, on average, immigrants have a lower intergenerational earnings mobility, also (on average) within groups with similar ethnic backgrounds. Immigrants with a relatively low intergenerational earnings mobility increased their average earnings more in the second generation, thereby supporting the idea that low intergenerational earnings mobility can be interpreted as a high degree of intergenerational transmission of human capital.
\end{abstract}

JEL: J15, J24, J61, J62.

KEYWORDS: intergenerational income mobility, intergenerational earnings correlation, Becker-Tomes model, ethnic capital.

\footnotetext{
* We thank Dan Anderberg, Mahmood Arai, Lars Behrenz, Anders Björklund, Jan Ekberg, Mikael Lindahl and Oskar Nordström Skans as well as participants in seminars given at the EEA Congress in Madrid, Institute for Social Research at Stockholm University, and the Departments of Economics at Uppsala, Gothenburg and Trondheim Universities for comments.

${ }^{a}$ Department of Economics, Växjö University, SE-351 95 Växjö, Sweden. E-mail: Mats.Hammarstedt@ @xu.se.

${ }^{\mathrm{b}}$ Department of Economics, Stockholm University, SE-106 91 Stockholm, Sweden and IZA Bonn. E-mail:

Marten.Palme@ne.su.se.
} 


\section{Introduction}

As in most other OECD countries, the number of immigrants has increased rapidly in Sweden in recent decades. In 2005, the number of foreign born residing in Sweden amounted to 11 percent of the population, which is about the same as in the US. Problems of integration on the labor market have recently been recognized both in Sweden and most other European welfare states (see e.g. Zimmermann, 2005). However, unlike most other European countries Sweden has, as a consequence of staying out of the Second World War, a fairly long history of immigration. This is reflected by about 25 percent of the population having at least one foreign-born parent.

Whether the large immigrant groups entering the European labor markets will ever fully assimilate has been subject to much less study than the corresponding question in the US - the "melting pot" analogy - partly because immigration has a much shorter (modern) history in Europe. Important institutional differences on the labor market, in the education system as well as the role of the family in the transmission of human capital between generations, suggest that there may be important differences in the possibilities of reaching long-term assimilation between the US and Europe in this respect.

In this study, we analyze intergenerational earnings mobility among immigrants in Sweden. The study relates to two different branches of the previous literature on intergenerational transmission of human capital. The first is intergenerational mobility between groups with different ethnic origins. ${ }^{1}$ On this issue, the results show that the group of immigrants changes places in the earnings distribution with the Swedish comparison group: the average 5.0 percent earnings disadvantage of immigrants in the first generation is reversed to a 1.6 percent advantage in the second generation. However, we find a diverging pattern between groups with different ethnic origins over the two generations: groups who did relatively well in the first generation do even better in the second and groups who did relatively badly in the first generation do even worse in the second. This is strikingly different from findings of previous studies on US data (see Borjas, 1993), which find a strong convergence to the mean in the second generation.

\footnotetext{
${ }^{1}$ See Borjas (1993) for a study on US data and Österberg (2000) or Rooth and Ekberg (2003) for studies on Swedish data.
} 
The second branch consists of studies on intergenerational income mobility (see Solon, 1999, for an overview of this literature, or Björklund and Jäntti, 1997, for a study on Swedish data). We study intergenerational earnings mobility within the entire group of immigrants, a comparison group of natives as well as groups with different ethnic origins. Less overall mobility is found within the immigrant group. Moreover, we also find heterogeneity between different immigrant groups in this respect. Finally, we relate the within group earnings mobility to the average outcome of the group in the second generation. We find that groups with relatively low mobility do relatively well in the second generation in terms of average earnings. One interpretation of this result is that groups of immigrants that make relatively large investments in the second generation get less earnings mobility and also, on average, higher earnings in the second generation.

Most empirical studies on intergenerational transmission of human capital and earnings mobility in economics depart, in one way or another, from the well-known Becker-Tomes (1986) model. Borjas (1992) extends the Becker-Tomes model by introducing "ethnic capital" working as an externality in the production of human capital. This model allows for persistence in the assimilation process, i.e., differences in average incomes between groups may persist over several generations. This, in turn, explains why there may be less intergenerational earnings mobility within the group of immigrants.

By showing that intergenerational mobility is lower also (on average) within groups of immigrants with similar ethnic backgrounds, we conclude that Borjas' model is not sufficient for explaining less intergenerational mobility among immigrants in our data. However, this result is not surprising in the sense that there are several reasons why the family may be more important for intergenerational transmission of human capital among immigrants than for natives. In general, access to, and influence of, society outside the family - such as educational systems and social networks - are likely to be more important for natives. The result that ethnic groups among immigrants with less intergenerational mobility are more successful on the labor market in the second generation further strengthens this conclusion.

We use a unique data set which, in addition to demographic information and data on educational attainments, contains information on labor earnings from 1975 and 1980 for all male immigrants arriving in Sweden before 1970. It also contains corresponding information on all their biological children obtained for the years 1997, 1998 and 1999. A native 
individual has been matched with each first-generation immigrant with respect to occupation, region of residence and age, to form a comparison sample of natives to the original data set. These data also contain corresponding information on the next generation. Because of the large size of the data set - almost 70,000 male second-generation immigrants, which is a total survey rather than a sample - we are able to divide the data into 20 sub-groups with respect to geographical origin, which allows for a separate analysis.

The paper is organized as follows. Section 2 discusses the implications of the Becker-Tomes model for intergenerational income mobility among immigrants. In Section 3, we describe the history of immigration to Sweden and immigration policy up to 1970. Section 4 describes the data used in this study and Section 5 presents the results. Section 6 concludes.

\section{Intergenerational Transmission of Human Capital and Intergenerational Income} Mobility

In Becker and Tomes' (1986) model for intergenerational transmission of human capital, the parent generation renounces a share of their consumption possibilities and invests it in the skill formation of their children. In addition to intergenerational transmission of "endowments", these investments generate the observed pattern of persistence in labor earnings over generations. An implication of allowing for heterogeneity between different groups of immigrants in the preferences for investing in the human capital of one's child in this model is that within groups of people with preferences for making relatively large investments, we will see a higher degree of earnings persistence over generations. Another implication is that these groups will, on average, improve their situation in the earnings distribution if there is a positive return on their human capital investment.

An overview of empirical studies on intergenerational earnings mobility in Handbook of Labor Economics (Solon, 1999) shows that earnings mobility seems to vary substantially between different countries. There are, however, several institutional differences, such as the financing of the education system and the degree of openness on the labor market, in addition to differences in preferences for investing in the human capital of the next generation, which may generate these differences. The institutional differences may also generate deviations in 
economic growth. Solon (1999) exemplifies a society with a very low degree of mobility as a "cast" society, where the position at the labor market is completely inherited. Obviously, such a society will generate very limited incentives for progress and development. However, in the other extreme, a society with complete earnings mobility over generations, there may be no intergenerational transmission of skills within families, which may also harm long-term economic growth and development. With respect to over all economic growth there are, thus, two counteracting effects.

The study of intergenerational transmission of human capital among immigrants involves several additional aspects as compared to conventional studies on intergenerational income mobility. Following Borjas (1993), an "open" society with a high degree of intergenerational mobility is, everything else equal, likely to attract unskilled workers in the first generation, since their children have a higher chance of improving their position on the labor market as compared to their parents. Conversely, a "closed" society, with a low degree of intergenerational mobility, is likely to attract skilled workers in the first generation, since their children are more likely to maintain the labor market position of their parents.

To study intergenerational mobility among different ethnic groups, Borjas (1992) extends the Becker and Tomes model by introducing "ethnic capital", which works as an externality in the human capital accumulation process. Thus, in this model, labor market outcome and income in the second generation does not only depend on parental investments but also on the average quality of the ethnic environment where parents make their investments. If the effect of "ethnic capital" is sufficiently strong, ethnic differences in labor market outcome and income in the first generation are likely to persist over several generations. A limitation with Borjas' extension of the Becker and Tomes model is, however, that it only explains persistence in the economic position. The model cannot explain why certain ethnic groups improve their relative income position in the child generation, whereas the relative income position of other ethnic groups deteriorates.

A further extension of the Becker and Tomes model is that different ethnic groups might have different preferences for investing in children's human capital. It is, for example, conceivable that immigrants originating from countries where the family is more important for funding higher and secondary education, e.g. the US, are more willing to invest in their children. Moreover, there is extensive anecdotal evidence that political refugees who, for political 
reasons, were restricted on the labor market in their country of origin, or had to leave prominent positions, are more inclined to be engaged in the careers of their children. This would primarily apply to immigrant groups originating from ex-communist countries in Eastern Europe and, to some extent, Latin American countries. Conversely, it is likely that workers who were recruited to jobs in the new country that were better than what they could have obtained in their country of origin give higher priority to their own careers. ${ }^{2}$

One implication of the Becker-Tomes model is, as explained above, that groups with low intergenerational earnings mobility, ceteris paribus, invest more in their children and therefore improve their average labor market outcome in the second generation. Above, we also discussed the possible relation between economic growth in a society and intergenerational transmission of human capital. Although immigrant groups may have different tastes for investing in the human capital of their children, they face the same institutional arrangements on the labor market and in the education system. Therefore, an implication of the Becker-Tomes model allowing for between-group heterogeneity in the preferences for investing in the human capital of the next generation is that groups where the within group intergenerational earnings mobility is relatively low will, on average, improve their relative position in the earnings distribution.

\section{Sweden's Immigration History 1910-1970}

The first-generation immigrants included in our sample arrived in Sweden between 1916 and 1970. Table 1 gives a brief description of different eras in Swedish immigration policy and the composition of immigrants entering Sweden during this period. In the first period described in the table, 1910-1940, immigration to Sweden was very limited. The annual average number of immigrants amounted to about 7,000, compared to an annual emigration of about 12,000, primarily to North America. One reason for the low emigration was the restrictive policies towards immigrants applied from 1917 and ahead. During the economic recession in the 1920's, the policy for immigrants to Sweden and other European countries became even more restrictive. In the 1930's, Sweden became a net immigration country. This

\footnotetext{
${ }^{2}$ As we will see in Section 3 on the history of immigration to Sweden, this could apply to immigrants originating from Southern Europe.
} 
was, however, primarily due to a decreased rate of emigration to the US and immigration to Sweden primarily consisted of return migration from the US.

Table 1. Composition of immigrants to Sweden and Swedish immigration and refugee policy 1910-1970.

\begin{tabular}{|c|c|c|c|}
\hline Point in time: & $\begin{array}{l}\text { Immigration and refugee } \\
\text { policy }\end{array}$ & Type of immigration & Major source countries \\
\hline $1910-1940$ & $\begin{array}{l}\text { Restrictive policy against } \\
\text { immigrants and refugees } \\
\text { from } 1917 \text { onwards }\end{array}$ & $\begin{array}{l}\text { Return migration from } \\
\text { North America and } \\
\text { immigrants from the } \\
\text { Nordic countries }\end{array}$ & $\begin{array}{l}\text { Nordic countries. Return } \\
\text { migrants from North } \\
\text { America }\end{array}$ \\
\hline 1940’s & $\begin{array}{l}\text { Less restrictive refugee } \\
\text { policy due to the Second } \\
\text { World War }\end{array}$ & $\begin{array}{l}\text { Refugee immigration due } \\
\text { to the second world war }\end{array}$ & $\begin{array}{l}\text { Nordic countries and } \\
\text { countries in Eastern } \\
\text { Europe }\end{array}$ \\
\hline \multirow[t]{5}{*}{ 1950’s } & $\begin{array}{l}\text { The common Nordic labor } \\
\text { market } 1954\end{array}$ & $\begin{array}{l}\text { Low educated labor force } \\
\text { migration }\end{array}$ & $\begin{array}{l}\text { Finland, other Nordic } \\
\text { countries, Italy, Greece }\end{array}$ \\
\hline & $\begin{array}{l}\text { Collective labor force } \\
\text { conveyance with } \\
\text { recruitment campaigns }\end{array}$ & $\begin{array}{l}\text { High educated labor force } \\
\text { migration }\end{array}$ & Western Europe \\
\hline & The 1953 Work & Refugee migration & Hungary \\
\hline & $\begin{array}{l}\text { Regulation of the OEEC } \\
\text { which gave non-Nordic } \\
\text { immigrants the right to } \\
\text { enter Sweden individually } \\
\text { and then apply for a work } \\
\text { permit and the Alien Act } \\
\text { of } 1953 \text { which gave } \\
\text { foreigners resident in } \\
\text { Sweden legal protection } \\
\text { and security in the } \\
\text { country. }\end{array}$ & & \\
\hline & $\begin{array}{l}\text { The Geneva convention of } \\
1951 \text { regarding different } \\
\text { classifications of refugees. }\end{array}$ & & \\
\hline \multirow[t]{2}{*}{ 1960’s } & $\begin{array}{l}\text { Restriction that non- } \\
\text { Nordic immigrants must } \\
\text { arrange for visas, }\end{array}$ & $\begin{array}{l}\text { Low educated labor force } \\
\text { migration }\end{array}$ & $\begin{array}{l}\text { Finland, other Nordic } \\
\text { countries, Yugoslavia }\end{array}$ \\
\hline & $\begin{array}{l}\text { employment and residence } \\
\text { before entering Sweden. }\end{array}$ & Refugee migration & Czechoslovakia \\
\hline
\end{tabular}

It was not until the Second World War that immigrants without previous ties to Sweden began arriving in significant numbers. From the 1940's and onwards, Sweden has had a large yearly average immigrant surplus. For the period 1940-1970, the average annual immigration amounted to about 29,000 individuals and the average annual emigration to about 14,000 individuals. Most of the emigrants during this period were former immigrants. 
In the 1940's, most of the immigrants were refugees from the Second World War. During the war, most refugees came from the neighboring Nordic countries and the Baltic States. Migration during the late 1940's mainly consisted of refugee immigrants from countries in Eastern Europe with Poland and the Baltic States as the dominating countries.

Immigration characteristics changed in the late 1940's. From the beginning of the 1950's until the early 1970's, immigration to Sweden was predominately labor force migration, which to a large extent depended on the economic cycle. Immigration increased in times of high demand for labor and decreased when demand for labor decreased. Labor force migration during the 1950's and 1960's was made possible by three institutional changes: First, the agreement about a common Nordic labor market in 1954, removing the needs for residence and work permits for immigrants from the Nordic countries. Second, the collective labor force conveyance with recruitment campaigns across Europe instituted by the Swedish Labor Market Board in co-operation with local unions and companies. Third, the approval of the 1953 Work Regulation of the OEEC and the Alien Act of 1954. The Alien Act of 1954 was designed to give foreigners resident in Sweden certain legal protection and security in the country and together with the Work Regulation of the OEEC, it made it possible for nonNordic immigrants to enter Sweden individually and apply for a work permit once there.

Labor force migration during the 1950's mainly consisted of immigrants from Finland, Western European countries such as West Germany, Belgium and the Netherlands, and Southern European countries such as Italy and Greece. Western European immigrants were in general better educated than those from the Nordic countries and Southern Europe. At the beginning of the 1960's, immigration from Yugoslavia started to increase. In the mid-1960's Finland, Yugoslavia and Greece were the dominating labor force migration countries. In that period, there was also labor force migration from Turkey.

The Alien Act of 1954 existed until the mid-1960s when it was changed under pressure from Swedish labor unions. In the mid-1960s, Swedish labor organizations saw immigrants as holding down the wage level for low paid workers. In 1968, the Swedish government imposed the restriction that non-Nordic immigrants must arrange their visas, employment and residence before they entered Sweden. However, these restrictions did not reduce the total labor force immigration. Non-Nordic immigration decreased, but there was instead an 
increase in Nordic immigration. The total labor force immigration reached its peak in the years around 1970, and it was not until the economic recession in the mid-1970s that labor immigration to Sweden decreased.

Refugee migration to Sweden was low during the 1950's and 1960's. There was refugee migration from Hungary in connection with the national uprising against Soviet domination in the mid-1950's and from Czechoslovakia in connection with the Soviet Union's assumption of power in the late 1960's.

The characteristics of the non-European immigration to Sweden have changed over the years. Prior to 1970, non-European immigration only constituted about 10 percent of total immigration to Sweden. The great majority of the immigrants from countries in Africa, Asia and the Middle East prior to 1970 were refugees. On the other hand, from migration from Latin America was to a large extent made up of return migrants with Swedish citizenship. However, in the mid-1970's, the number of refugees from non-European countries started to increase. During the 1970's, non-European immigrants constituted about 25 percent of total immigration to Sweden. Most of the non-European immigrants during the 1970's were refugees from Latin America. During the 1980's and 1990's, the share of non-European immigrants amounted to about 50 percent of total immigration to Sweden and these were mostly dominated by refugees from Asia and Africa.

\section{Data and Measurement}

Our data set, obtained from Statistics Sweden, contains information on all foreign-born individuals who were resident and gainfully employed in Sweden in 1970 and their (biological) children. ${ }^{3}$ The foreign-born individuals were aged between 20 and 64 in 1975 and 1980. The children born in Sweden by those individuals were aged between 20 and 64 in 1997, 1998 and 1999. This means that our sample contains foreign-born individuals who immigrated to Sweden between 1916 and 1969.

\footnotetext{
${ }^{3}$ Björklund and Chadwick (2003) found that the definition of children may be of importance in measuring intergenerational mobility. The association between son's income and father's income is weaker the less they lived together.
} 
Table 2 shows how the data for the study have been designed. For each first-generation immigrant in the sample, a native Swede was randomly selected from a cell with the same age, gender, geographical residence (county) and occupational status (at the three-digit level from the SNI-code, which means 282 different occupations) as the immigrant.

Table 2. Description of how the data has been designed.

\begin{tabular}{|c|c|}
\hline & Explanation \\
\hline First-generation immigrant & $\begin{array}{l}\text { All first-generation immigrants gainfully employed or } \\
\text { self-employed in Sweden } 1970\end{array}$ \\
\hline Native twins & $\begin{array}{l}\text { Native individuals with the same age, gender, county of } \\
\text { residence and occupational status as their foreign born } \\
\text { counterparts by the year } 1970\end{array}$ \\
\hline Second-generation immigrant & Children of foreign born fathers \\
\hline Native comparison group & Children with both parents born in Sweden \\
\hline Birth year for foreign born fathers and native twins & $1916-1955$ \\
\hline $\begin{array}{l}\text { Birth year for second-generation immigrants and native } \\
\text { comparison groups }\end{array}$ & $1935-1977$ \\
\hline Fathers earnings observed & 1975,1980 \\
\hline $\begin{array}{l}\text { Sons earnings and social assistance dependency } \\
\text { observed }\end{array}$ & 1997, 1998, 1999 \\
\hline Earnings definition & $\begin{array}{l}\text { All fathers with positive earnings in } 1975 \text { and } 1980 \\
\text { All sons with positive earnings in } 1997,1998 \text { and } 1999\end{array}$ \\
\hline
\end{tabular}

We use data on first-generation immigrants and their native twins from the 1975 and 1980 Censuses. All sons aged 20 years or older in 1997 are linked to their parents. The secondgeneration immigrants and children of natives were observed in 1997, 1998 and 1999.

The second-generation immigrants have been divided into twenty groups by their fathers' region of origin, with the emigration pattern to Sweden as a starting point. The groups selected for our analysis are immigrants from Finland, other Nordic countries, former Yugoslavia, Greece, Italy, Turkey, the Baltic States, the former Soviet Union, former Czechoslovakia, Hungary, Poland, Germany, France, United Kingdom, the Netherlands, the Middle East, Africa, Asia (except the Middle East), Latin America and the United States and Canada. A comparison group containing children of native-born twins has been selected for each one of the sixteen immigrant groups. In the native comparison groups, the father was born in Sweden. The groups and the number of individuals in each group are presented in Table 3. 
Table 3. Number of individuals and the share of individuals with a native mother in different groups of second-generation immigrants.

\begin{tabular}{|c|c|c|c|c|}
\hline & Father's region of birth & $\begin{array}{l}\text { Number of male } \\
\text { second-generation } \\
\text { immigrants }\end{array}$ & $\begin{array}{l}\text { Share of second- } \\
\text { generation } \\
\text { immigrants with a } \\
\text { native born mother } \\
\text { (percent) }\end{array}$ & $\begin{array}{l}\text { Number of children } \\
\text { of native "twins" }\end{array}$ \\
\hline 1 & Finland & 25,674 & 35.8 & 19,477 \\
\hline 2 & Other Nordic countries & 14,614 & 70.3 & 10,865 \\
\hline 3 & Former Yugoslavia & 4,262 & 28.7 & 3,369 \\
\hline 4 & Greece & 1,029 & 29.5 & 785 \\
\hline 5 & Italy & 1,389 & 65.2 & 1,160 \\
\hline 6 & Turkey & 408 & 32.3 & 310 \\
\hline 7 & Baltic States & 4,327 & 51.6 & 3,213 \\
\hline 8 & Former Soviet Union & 1,393 & 36.7 & 963 \\
\hline 9 & Czechoslovakia & 1,058 & 40.8 & 930 \\
\hline 10 & Hungary & 2,515 & 49.5 & 2,064 \\
\hline 11 & Poland & 1,484 & 45.1 & 1,137 \\
\hline 12 & Germany & 7,383 & 64.5 & 5,828 \\
\hline 13 & France & 357 & 79.0 & 287 \\
\hline 14 & United Kingdom & 592 & 81.3 & 501 \\
\hline 15 & The Netherlands & 754 & 67.0 & 528 \\
\hline 16 & Middle East & 255 & 56.1 & 160 \\
\hline 17 & Africa & 470 & 66.8 & 291 \\
\hline 18 & Asia & 456 & 74.3 & 326 \\
\hline 19 & Latin America & 246 & 74.0 & 176 \\
\hline 20 & United States and Canada & 1,832 & 89.7 & 1,360 \\
\hline \multicolumn{5}{|c|}{ Pooled groups of second-generation immigrants } \\
\hline 1 & Nordic countries & 40,288 & 48.3 & 30,342 \\
\hline 2 & Southern Europe and Turkey & 7,088 & 36.2 & 5,624 \\
\hline 3 & Eastern Europe & 10,777 & 47.2 & 8,307 \\
\hline 4 & $\begin{array}{l}\text { Western Europe, US and } \\
\text { Canada }\end{array}$ & 10,918 & 70.3 & 8,504 \\
\hline 5 & Africa and Middle East & 725 & 63.0 & 451 \\
\hline 6 & Latin America and Asia & 702 & 74.2 & 502 \\
\hline
\end{tabular}

Table 3 shows the great majority of second-generation immigrants to be sons of fathers originating from the Nordic countries. It also shows that the share of second-generation immigrants born by native mothers varies between the groups. Sons of labor-force migrants, e.g. originating from Finland, Greece, Turkey or Yugoslavia, are born by a foreign-born mother to a larger extent than other second-generation immigrants. Only about 30 percent in these groups have Swedish mothers. In the groups originating from Western Europe, Asia and Latin America, the share of second-generation immigrants born by a native mother in many cases exceeds 70 percent. Among second-generation immigrants with fathers born in the United States or Canada, the share with a native mother is almost 90 percent. 
Table 4 also shows that the age of the second-generation immigrants varies between different groups. The average age among sons with fathers originating from the Baltic States and the former Soviet Union is about 40 years. The average age among sons to immigrants from countries in Western Europe, the Nordic countries (except Finland) and countries in Eastern Europe is about 35 years. As regards second-generation immigrants with fathers originating from Southern Europe or non-European countries, the average age is considerably lower. For second-generation immigrants with fathers originating from former Yugoslavia, Greece, Turkey and the Middle East, the average age is below 30 years.

Table 4. Average age and percentage share of individuals with earnings from labor $>0$ in 1997, 1998 and 1999. Second-generation immigrants and native comparison groups.

\begin{tabular}{|c|c|c|c|c|c|}
\hline \multirow[b]{2}{*}{ No. } & \multirow[b]{2}{*}{ Father's region of birth } & \multicolumn{2}{|c|}{ Average age (years) } & \multicolumn{2}{|c|}{$\begin{array}{l}\text { Share of individuals with earnings } \\
\text { from labor >0 in 1997, } 1998 \text { and } \\
1999 \text { (percent) }\end{array}$} \\
\hline & & $\begin{array}{l}\text { Second- } \\
\text { generation } \\
\text { immigrants }\end{array}$ & $\begin{array}{l}\text { Children of } \\
\text { natives }\end{array}$ & $\begin{array}{l}\text { Second- } \\
\text { generation } \\
\text { immigrants }\end{array}$ & $\begin{array}{l}\text { Children of } \\
\text { natives }\end{array}$ \\
\hline 1 & Finland & 33.1 & 34.6 & 79.1 & 72.9 \\
\hline 2 & Other Nordic countries & 38.8 & 39.8 & 79.7 & 72.7 \\
\hline 3 & Former Yugoslavia & 29.0 & 32.6 & 70.8 & 71.5 \\
\hline 4 & Greece & 28.5 & 33.1 & 56.9 & 75.2 \\
\hline 5 & Italy & 33.6 & 36.6 & 75.0 & 72.5 \\
\hline 6 & Turkey & 28.8 & 34.6 & 60.8 & 65.8 \\
\hline 7 & Baltic States & 40.1 & 41.5 & 81.7 & 72.8 \\
\hline 8 & Former Soviet Union & 42.3 & 43.4 & 78.3 & 73.1 \\
\hline 9 & Czechoslovakia & 36.1 & 37.2 & 80.3 & 75.9 \\
\hline 10 & Hungary & 34.2 & 36.0 & 76.3 & 73.3 \\
\hline 11 & Poland & 39.6 & 41.8 & 76.6 & 70.9 \\
\hline 12 & Germany & 35.8 & 36.9 & 82.0 & 73.0 \\
\hline 13 & France & 36.4 & 36.8 & 78.2 & 65.5 \\
\hline 14 & United Kingdom & 34.1 & 36.2 & 80.2 & 74.1 \\
\hline 15 & The Netherlands & 36.5 & 37.4 & 81.2 & 73.5 \\
\hline 16 & The Middle East & 28.6 & 31.7 & 66.3 & 70.6 \\
\hline 17 & Africa & 30.8 & 34.4 & 70.4 & 73.2 \\
\hline 18 & Asia & 34.8 & 38.3 & 77.4 & 76.1 \\
\hline 19 & Latin America & 33.4 & 36.6 & 79.7 & 73.9 \\
\hline 20 & United States and Canada & 43.3 & 43.7 & 81.0 & 72.2 \\
\hline \multicolumn{6}{|c|}{ Pooled groups of second-generation immigrants } \\
\hline 1 & Nordic countries & 35.2 & 36.5 & 79.3 & 72.8 \\
\hline 2 & Southern Europe and Turkey & 29.8 & 33.6 & 77.4 & 71.9 \\
\hline 3 & Eastern Europe & 38.5 & 39.9 & 79.2 & 73.0 \\
\hline 4 & $\begin{array}{l}\text { Western Europe, US and } \\
\text { Canada }\end{array}$ & 35.8 & 36.9 & 81.6 & 72.7 \\
\hline 5 & Africa and Middle East & 30.0 & 33.4 & 69.0 & 72.3 \\
\hline 6 & Latin America and Asia & 34.3 & 37.7 & 78.2 & 75.3 \\
\hline
\end{tabular}

Finally, Table 4 shows that the share of second-generation immigrants with positive earnings from labor varies between the groups. Among second-generation immigrants with fathers 
originating from the Nordic countries, Asia, Latin America, Western and Eastern Europe, this share is between 85 and 90 percent. For some of the Southern European groups and the Middle East, the share is considerably lower.

\section{Results}

\subsection{Relative earnings of first- and second-generation immigrants}

Table 5 compares the economic position of first- and second-generation immigrants with that of the native comparison groups. Since these results are obtained on the entire population of immigrants, we do not report standard errors. The first two columns show the results for firstgeneration immigrants. In the first of these columns, the average earnings of the immigrants are compared to the average of the twin native group. This comparison can be interpreted as the difference conditional on occupational status and local labor market differences. The second column shows the results of the comparison when all native twin groups have been pooled together, i.e., the difference compared to the natives with average occupational status and the local labor market of the entire immigrant group. To control for differences due to earnings variation over the life cycle, all individual earnings are measured as deviations from a cubic polynomial in age, which is estimated on the entire data set. 
Table 5. Differences in log earnings between male first-generation immigrants and native comparison groups in 1975 and 1980 (pooled data) and difference in earnings and use of social assistance between male second-generation immigrants and native comparison groups in 1997, 1998 and 1999 (pooled data).

\begin{tabular}{|c|c|c|c|c|c|c|c|}
\hline No. & $\begin{array}{l}\text { Father's region of } \\
\text { birth }\end{array}$ & $\begin{array}{l}\text { Differences } \\
\text { in log } \\
\text { earnings } \\
\text { between } \\
\text { male } \\
\text { immigrants } \\
\text { and native } \\
\text { twins }\end{array}$ & $\begin{array}{l}\text { Differences } \\
\text { in log } \\
\text { earnings } \\
\text { between } \\
\text { male } \\
\text { immigrants } \\
\text { and all } \\
\text { natives }\end{array}$ & $\begin{array}{l}\text { Differences } \\
\text { in log } \\
\text { earnings } \\
\text { between } \\
\text { male } \\
\text { second- } \\
\text { generation } \\
\text { immigrants } \\
\text { and their } \\
\text { native twins }\end{array}$ & $\begin{array}{l}\text { Differences } \\
\text { in log } \\
\text { earnings } \\
\text { between } \\
\text { male } \\
\text { second- } \\
\text { generation } \\
\text { immigrants } \\
\text { and all } \\
\text { natives }\end{array}$ & $\begin{array}{l}\text { Differences } \\
\text { in use of } \\
\text { social } \\
\text { assistance } \\
\text { between } \\
\text { male } \\
\text { second- } \\
\text { generation } \\
\text { immigrants } \\
\text { and their } \\
\text { native twins }\end{array}$ & $\begin{array}{l}\text { Differences } \\
\text { in use of } \\
\text { social } \\
\text { assistance } \\
\text { between } \\
\text { male } \\
\text { second- } \\
\text { generation } \\
\text { immigrants } \\
\text { and all } \\
\text { natives }\end{array}$ \\
\hline 1 & Finland & -0.032 & -0.029 & 0.012 & 0.004 & 0.020 & 0.025 \\
\hline 2 & $\begin{array}{l}\text { Other Nordic } \\
\text { countries }\end{array}$ & -0.050 & -0.082 & 0.038 & 0.026 & 0.017 & 0.016 \\
\hline 3 & Former Yugoslavia & -0.092 & -0.105 & -0.175 & -0.184 & 0.041 & 0.032 \\
\hline 4 & Greece & -0.149 & -0.223 & -0.399 & -0.377 & 0.048 & 0.037 \\
\hline 5 & Italy & -0.049 & -0.067 & -0.024 & -0.063 & 0.021 & 0.017 \\
\hline 6 & Turkey & -0.262 & -0.248 & -0.232 & -0.305 & 0.064 & 0.054 \\
\hline 7 & Baltic States & -0.014 & 0.021 & 0.138 & 0.153 & -0.001 & -0.013 \\
\hline 8 & Soviet Union & -0.015 & -0.120 & 0.048 & 0.061 & 0.001 & 0.009 \\
\hline 9 & Czechoslovakia & -0.063 & 0.002 & 0.038 & 0.047 & -0.010 & -0.013 \\
\hline 10 & Hungary & -0.090 & -0.062 & -0.071 & -0.065 & 0.032 & 0.019 \\
\hline 11 & Poland & -0.184 & -0.188 & 0.087 & 0.031 & 0.002 & 0.009 \\
\hline 12 & Germany & -0.005 & 0.002 & 0.079 & 0.087 & -0.005 & -0.009 \\
\hline 13 & France & -0.205 & -0.152 & -0.103 & -0.096 & 0.024 & 0.011 \\
\hline 14 & United Kingdom & -0.077 & -0.006 & -0.111 & -0.103 & 0.025 & 0.021 \\
\hline 15 & The Netherlands & -0.063 & -0.048 & 0.063 & 0.123 & -0.002 & -0.002 \\
\hline 16 & The Middle East & -0.276 & -0.200 & -0.251 & -0.295 & 0.073 & 0.055 \\
\hline 17 & Africa & -0.284 & -0.193 & -0.225 & -0.359 & 0.088 & 0.053 \\
\hline 18 & Asia & -0.090 & 0.002 & -0.019 & -0.024 & 0.005 & -0.007 \\
\hline 19 & Latin America & -0.141 & -0.094 & 0.238 & 0.086 & -0.003 & -0.009 \\
\hline 20 & $\begin{array}{l}\text { United States and } \\
\text { Canada }\end{array}$ & -0.041 & -0.092 & 0.047 & 0.060 & -0.012 & -0.022 \\
\hline \multirow{2}{*}{\multicolumn{2}{|c|}{ Average difference }} & & -0.050 & & 0.016 & & 0.017 \\
\hline & & \multicolumn{4}{|c|}{ Pooled groups of second-generation immigrants } & & \\
\hline 1 & Nordic countries & -0.038 & -0.047 & 0.022 & 0.014 & 0.021 & 0.022 \\
\hline 2 & $\begin{array}{l}\text { Southern Europe } \\
\text { and Turkey }\end{array}$ & -0.103 & -0.123 & -0.160 & -0.182 & 0.037 & 0.033 \\
\hline 3 & Eastern Europe & -0.065 & -0.047 & 0.060 & 0.060 & 0.008 & 0.002 \\
\hline 4 & $\begin{array}{l}\text { Western Europe, US } \\
\text { and Canada }\end{array}$ & -0.026 & -0.001 & 0.059 & 0.069 & -0.003 & -0.007 \\
\hline 5 & $\begin{array}{l}\text { Africa and Middle } \\
\text { East }\end{array}$ & -0.280 & -0.196 & -0.236 & -0.342 & 0.085 & 0.054 \\
\hline 6 & $\begin{array}{l}\text { Latin America and } \\
\text { Asia }\end{array}$ & -0.108 & -0.020 & 0.078 & 0.015 & 0.002 & -0.007 \\
\hline \multicolumn{2}{|c|}{ Average difference } & & -0.050 & & 0.016 & & 0.017 \\
\hline
\end{tabular}

The results show that the first-generation immigrants on average earned about 5.0 percent less than the native group. The comparison with the entire native group shows there to be substantial differences between the immigrant groups in this respect. Immigrants from Turkey, Greece, the Middle East and Africa earned on average 20 to 25 percent less than 
natives in the first generation, while immigrants from the Baltic States, Germany and the United Kingdom on average earned somewhat more or about the same as natives in the first generation. The comparison with the native comparison group shows that a varying part if the earnings differentials compared to natives can be referred to differences in composition with respect to occupational status and local labor market. For example, immigrants from the Baltic States had a 1.4 percent earnings disadvantage when compared to the native twin group, but an earnings advantage compared to the entire native group. This result is probably due to this group predominantly being employed in occupations requiring high skills. However, for the African group, the earnings disadvantage can be referred to this group earning less within its occupations and local labor markets. The smallest earnings differentials compared to the native comparison group are found among the geographically, and in some cases culturally, close immigrant groups from Finland, Other Nordic countries, Germany, the Soviet Union and the Baltic States.

The third and fourth columns show the corresponding results for second-generation immigrants. However, since the native comparison group now consists of the sons of the firstgeneration native group, it does not maintain its characteristic of being matched on the characteristics of the immigrant group, i.e., the interpretation of the remaining earnings differential as the differential "controlling" for compositional differences cannot be maintained. On the other hand, it gives a measure on how successful the group of secondgeneration immigrants has been as compared to a group of natives with a similar socioeconomic background.

A comparison of the average relative earnings of the entire group of second-generation immigrants shows that the 5.0 percent earnings disadvantage in the first generation is reversed to a 1.6 percent earnings advantage for second-generation immigrants. However, Table 5 also shows the average earnings disadvantage to have increased for some groups. This is most apparent for the group originating from Turkey, Greece, the Middle East and Africa. Turning to second-generation immigrants from the Nordic countries, Eastern Europe, Western Europe and Latin America, we find second-generation immigrants from these groups to have increased their relative earnings as compared to natives in the second-generation. Secondgeneration immigrants from the Baltic States earn about 15 percent more than natives in the second-generation. For second-generation immigrants from Czechoslovakia or the Soviet Union, the corresponding earnings advantage compared to natives amounts to about 6 and 5 
percent, respectively, while second-generation immigrants originating from Germany and the Netherlands earn about 9 and 12 percent more than natives in the second-generation. Secondgeneration immigrants from Latin America earn more than natives in the second-generation. For this group, the earnings advantage compared to natives amounts to almost 9 percent.

For the second-generation immigrant group, we have an additional outcome measure: the share of the group that received social assistance in 1997, 1998 and 1999. The results of the comparison of this outcome measure are shown in columns five and six. The results reveal differences between second-generation immigrants and their native comparison groups in their use of social assistance. The largest difference is found among male second-generation immigrants originating from Turkey, the Middle East and Africa. The share of social assistance recipients is more than five percentage points higher among second-generation immigrants with fathers originating from Turkey, the Middle East or Africa than among the native comparison group. Among male second-generation immigrants from Greece, the difference with respect to the native comparison group amounts to almost four percent.

There are six second-generation immigrant groups - consisting of the Baltic States, Czechoslovakia, Germany, the Netherlands, the United States and Canada and Latin America - that are relatively successful as regards both earnings and social assistance. There is also a middle group consisting of Finland, Other Nordic countries, Italy, Hungary, Poland, the former Soviet Union, France and United Kingdom; and a less successful group consisting of former Yugoslavia, Greece, Africa, the Middle East and Turkey. Finally, there is one outlier in the relation between average earnings differential and dependence on social assistance: Second-generation immigrants originating from Asia have relatively low earnings, but also a small share that receives social assistance.

To assess the intergenerational mobility between groups of immigrants, we estimate a relationship of the relative earnings of the two generations. This is given by:

$$
y_{s}=\underset{(0.040)}{0.074}+\underset{(0.319)}{1.425} y_{f}, \quad \mathrm{R}^{2}=52.6, \quad \mathrm{~N}=20
$$

where $y_{s}$ is the relative earnings of the second-generation and $y_{f}$ is the relative earnings of the first generation and the standard errors are reported in parentheses. 
The constant in this regression model has the interpretation of mobility vis-à-vis the entire group of natives, i.e., about a 7 percent increase in relative earnings for the entire group. ${ }^{4}$ The slope coefficient measures mobility between the different immigrant groups. If it is zero, there is no correlation between the economic positions of the first- and second-generation immigrants and if it is one, all groups maintain their position in average earnings relative to the group of natives. If it is between zero and one, it can be interpreted as "regression towards the mean", i.e., the share of a relative earnings advantage maintained in the second generation. The point estimate on 1.4 could be interpreted as an earnings divergence between groups in the second generation: between-group average earnings differentials are reinforced in the second generation.

This pattern is further highlighted in Figure 2, which shows average labor earnings relative to the native group in the first and second generations, respectively. The comparatively small earnings disadvantages of the groups originating from the Nordic countries, Latin America, Eastern and Western Europe are reversed to earnings advantages in the second generation, while the large earnings disadvantages of the groups originating from Southern Europe, the Middle East and Africa are reinforced in the second generation.

The results from Borjas $(1992,1993)$ shows that in the United States the highest relative earnings are found among first-generation immigrants from countries in Western and Eastern Europe. First-generation immigrants in these groups earn more than natives in the United States. Furthermore, the relative earnings advantage for these immigrant groups remains in the second generation but the advantage compared to natives is smaller in the second than in the first generation. Borjas results also shows that first-generation immigrants from Mexico, Cuba and Greece have the lowest relative earnings among first-generation immigrants in the United States. First-generation immigrants from these countries earn less than natives in the first-generation but the relative earnings in these groups improved in the second-generation. In general the earnings disadvantage were smaller in the second-generation than in the first among these groups. Thus, the results by Borjas indicate regression towards the mean across immigrant generations in the United States.

\footnotetext{
${ }^{4}$ The average convergence in relative earnings between natives and second-generation immigrants was estimated for the entire population. Note, however, that this estimate refers to a different weighting of the groups than the 6.6 percent convergence presented above and it imposes a restrictive functional form that can also explain some of the discrepancy.
} 
Figure 1. Relative labor earnings of first- and second-generation immigrants compared to natives.

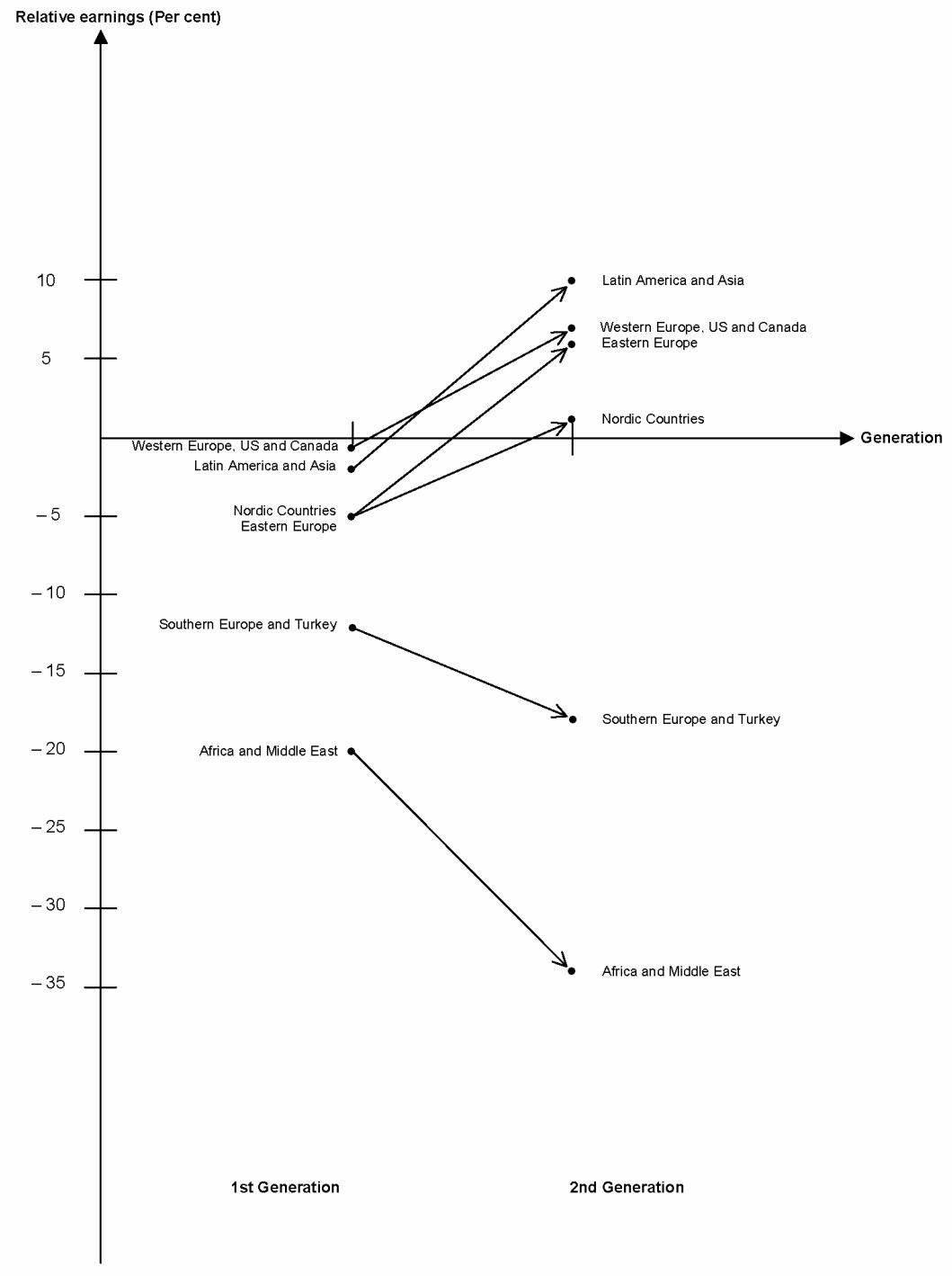

To sum up, although the average labor market earnings of second-generation immigrants exceeded those of the native comparison group, the results show there to be great differences in the economic position between different groups of second-generation immigrants in Sweden. Especially among immigrants from non-European and Southern European countries are the yearly earnings lower than among their native comparison groups. Furthermore, for immigrants from Africa and especially Southern European countries, the difference in yearly earnings compared to natives seems to be larger in the second than in the first generation. Second-generation immigrants from these regions also have a higher rate of social assistance recipients than natives. For other groups, such as the Nordic countries, and some countries in 
Eastern and Western Europe, immigrants seem to do better in the second generation than in the first as compared to natives. Finally, for some groups, such as immigrants from Hungary, France and the United Kingdom, the difference in earnings seems to be smaller between second-generation immigrants and the native comparison group than among first-generation immigrants and the native comparison group.

\subsection{Intergenerational mobility by country of origin}

There are several methodological problems related to the estimation of intergenerational correlation in labor market outcomes. Some of these are related to measurement problems of labor income for the parent generation. Solon (1992) shows that if observed labor earnings can be measured as the sum of a permanent and a transitory component, i.e., $y_{f i t}=y_{f i}+v_{f i t}$ the father's earnings and $y_{s i t}=y_{s i}+v_{s i t}$ for the son's earnings, the OLS regression of $y_{s i t}$ on $y_{\text {fit }}$ yields inconsistent estimates of $r$. The asymptotic bias, which has a very similar interpretation as "attenuation bias" in the presence of measurement errors, is given by the following expression:

$\left.p \lim \hat{r}=r s_{y f}^{2} / \mid s_{y f}^{2}+s_{r f}^{2}\right)<r$

where $s_{y f}^{2}$ is the variance in the permanent component of parent generation labor earnings and $s_{r f}^{2}$ the variance in the transitory one.

Another potential problem with the regression approach for measuring the intergenerational correlation in labor earnings is that it requires that the variance in labor earnings between individuals does not change over generations, else it will measure $r s_{y f}^{2} / s_{y s}^{2}$. An alternative approach, which does not suffer from this deficiency, is to directly estimate the correlation coefficient. The disadvantage of this estimator is, as once more shown by Solon (1992), that it has a negative asymptotic bias, also if there is only a non-zero variation in the transitory component of the second generation's labor earnings, the dependent variable in the regression approach. This is shown by the following expression: 
$p \lim R=r s_{y}^{2} / \sqrt{\left.\left(s_{y}^{2}+s_{n f}^{2}\right) \mid s_{y}^{2}+s_{n s}^{2}\right)}<r$.

As a sensitivity analysis, we use both estimators in the empirical analysis.

A third source of inconsistency originates from the measurement of life-time earnings of the second generation. Haider and Solon (2005) shows that any regression model that uses annual earnings as a proxy for life-time earnings may give inconsistent estimates if there is earnings growth rate heterogeneity. Their empirical analysis shows that the problem is more severe if annual earnings data for relatively young workers - younger than age 35 - or relatively old ones - older than age 45 - are used, since the association between these earnings information and life-time earnings is relatively weak. ${ }^{5}$

We use two different strategies for dealing with the asymptotic bias due to the difficulties in measuring the lifetime earnings of the first-generation. First, we use labor earnings averaged over annual earnings in 1975 and 1980, which can be observed in the data. Although this strategy will diminish the asymptotic bias, the estimator will still be inconsistent. However, since our primary interest in this study is to compare different immigrant groups, our analysis will only be affected to the extent that different groups have different variances in their transitory earnings component. Second, we use educational attainments of the parent generation as instrument for the average annual earnings. Although this approach gives consistent estimates of intergenerational correlation in earnings, the drawback, which applies to all IV estimates, is the efficiency loss compared to OLS.

The data on parental generation education is obtained from the 1990 census and contains information on highest education in 9 levels: the lowest level is the basic compulsory level and the highest is $\mathrm{PhD}$. For a large share, 16.6 percent among immigrants and 15.4 percent of the native comparison group, information on the education level is missing. To some extent, this high rate of missing values is related to this data being obtained ten years later than the earnings data, i.e., a large share having passed away or emigrated during that time. In the 2SLS estimation, we use dummy variables for each education level as instrumental variables. Missing information on education is used as an additional category.

\footnotetext{
${ }^{5}$ See Böhlmark and Lindquist (2005) for a study of this on Swedish data.
} 
For the third source of inconsistency, stemming from the measurement of life-time earnings of the second generation, we have to rely on the usual assumption of association between annual and life-time earnings described above. However, again, our main interest is on differences between groups in the population. This means that the inconsistency is only problematic if it is different for different groups. In this case such differences can arise if there are between-group differences in earnings growth rate heterogeneity or if the age of the second generation groups are very different. Although descriptive statistics shows that the average ages are quite similar, differences in growth rate heterogeneity could not be tested. There are, however, no obvious reasons to why they should be substantially different.

As described in Section 3, we have information on earnings for the second generation, the dependent variable in the regression models, from three years: between 1997 and 1999. To use all these observations in the estimation, we include year effects in the specification and also allow for general dependence over time for observations from the same individual and also between observations from siblings, to account for both cross-sectional correlation (within families) and autocorrelation for individual earnings over time (see e.g. Moulton, 1986).

To control for individual earnings differentials over the life cycle, we use a quadratic polynomial in age for both the first and second generation, i.e.,

$y_{f i}=b_{f 0}+b_{f 1} a g e_{i}+b_{f 2} a g e_{i}^{2}+u_{f i}$,

and

$$
y_{s i}=b_{s 0}+b_{s 1} a g e_{i}+b_{s 2} a g e_{i}^{2}+u_{s i} \text {. }
$$

Substituting this into the AR(1) process assumed for the correlation over generations, we get

$$
y_{s i}=\left(b_{s 0}-r b_{f 0}\right)+r y_{f i}+b_{s 1} a g e_{i}+b_{s 2} a g e_{i}^{2}-r b_{f 1} a g e_{i}-r b_{f 2} a g e_{i}^{2}+e_{i}+u_{i s}-r u_{i f} \text {. }
$$

For estimating $r$, we use both the regression model (5) estimate and, as a sensitivity analysis, the correlation coefficient of the residuals from the regressions in (3) and (4).

The results are shown in Table 6. The first two columns show the result from the OLS regression model for second-generation immigrants with different geographical origins and the native comparison group, respectively. Column 4 shows results for the different groups of second-generation immigrants when the correlation coefficient, instead of the regression 
model, has been used as an estimator and, finally, column 6 shows the estimates from the IV model.

The estimates of the overall difference in intergenerational income mobility between natives and immigrants show natives to have higher inter-generational earnings mobility. The estimated levels are much higher for the IV estimator, which is expected since we know that the other two estimators have a downward asymptotic bias. It can also be seen that the precision of the IV model is inferior as compared to the OLS one, since the standard errors are about three times larger. The difference between immigrants and natives is, nevertheless, statistically significant in all models.

To investigate to what extent the differences in intergenerational earnings mobility can be attributed to "ethnic factors", as suggested by Borjas (1992), we calculate the weighted average of the measured earnings mobility within each of the included groups with the same ethnic background. If the difference in intergenerational mobility between immigrants and natives primarily could be attributed to ethnic factors, we would see a very similar degree of intergenerational earnings mobility between natives and immigrants within groups of immigrants with similar ethnic backgrounds. Conversely, if there are other reasons to the observed differences, we would observe differences also within groups of immigrants with similar ethnic backgrounds compared to natives.

The results from this exercise, which are presented in the last row of Table 6 , show that these estimates are, as expected, smaller than the corresponding ones applying to the entire group of immigrants with different ethnic backgrounds. However, they are very close to the ones for the entire group, suggesting a very limited role for ethnic factors in explaining the overall difference between immigrants and natives in intergenerational earnings mobility.

Turning to the estimates of mobility within each group it is, once more, apparent that the level of the IV estimates is much higher than the OLS ones. However, this time the precision of the IV estimates is more problematic, since we cannot use them for establishing significant differences between groups. For some groups, e.g. the group originating from Turkey, the bad precision of the IV estimates is related to little variation and a high rate of missing values in the variable measuring father's education. However, the result in Table 6 shows the point estimates of the three estimation procedures, with a few exceptions, to give a very similar 
rank. The groups with the lowest mobility, i.e. the highest intergenerational correlation, are those originating from Latin America, France, the US or Canada. The highest mobility is estimated for those originating from the Middle East or Turkey. Six groups, those originating from Finland, Other Nordic countries, the Baltic States, Hungary, Germany, the US and Canada have significantly lower mobility for the OLS estimates than the entire group of natives. No group has significantly higher mobility than the group of natives.

As is evident from the results shown in Table 6, the precision of these estimates is very low for some groups of immigrants also in the OLS model. However, the results are however similar within groups of immigrants originating from areas from the same part of the world. Table 6 also shows the results from an additional analysis where, in order to increase the precision of the estimates, we have pooled the original 20 groups of immigrants into six larger groups. These results confirm that pattern from the previous analysis: The lowest mobility is within the groups originating from Western Europe, the United States and Canada, countries in Eastern Europe, Latin America and Asia. The second highest mobility is in the group originating from Southern Europe and the highest mobility is in the group originating from the Middle East and Africa. A comparison of the results from the OLS model for the groups originating from Africa, the Middle East or Southern Europe with those originating from Eastern Europe shows mobility to be significantly higher in the two former groups. Once more, the results of intergenerational mobility within the comparison groups of natives never differ significantly from each other. 
Table 6. Estimates of within immigrant group or native comparison group intergenerational earnings mobility. (Standard errors within parentheses).

\begin{tabular}{|c|c|c|c|c|c|c|c|}
\hline Geographic origin & $\begin{array}{l}\text { Regression } \\
\text { estimates. } \\
\text { Second } \\
\text { generation } \\
\text { immigrants }\end{array}$ & $\begin{array}{l}\text { Regression } \\
\text { estimates. } \\
\text { Native } \\
\text { comparison } \\
\text { group }\end{array}$ & $\begin{array}{c}\text { Rank. } \\
\text { Second } \\
\text { generation } \\
\text { immigrants }\end{array}$ & $\begin{array}{l}\text { Correlation } \\
\text { coefficient. } \\
\text { Second } \\
\text { generation } \\
\text { immigrants }\end{array}$ & $\begin{array}{l}\text { Rank. } \\
\text { Second } \\
\text { generation } \\
\text { immigrants }\end{array}$ & $\begin{array}{c}\text { IV. } \\
\text { Second } \\
\text { generation } \\
\text { immigrants }\end{array}$ & $\begin{array}{c}\text { Rank. } \\
\text { Second } \\
\text { generation } \\
\text { immigrants }\end{array}$ \\
\hline 1. Finland & $\begin{array}{c}0.183 \\
(0.009)\end{array}$ & $\begin{array}{c}0.124 \\
(0.008)\end{array}$ & 12 & $\begin{array}{c}0.104 \\
(0.003)\end{array}$ & 13 & $\begin{array}{c}0.343 \\
(0.029)\end{array}$ & 11 \\
\hline $\begin{array}{l}\text { 2. Other Nordic } \\
\text { countries }\end{array}$ & $\begin{array}{c}0.209 \\
(0.011)\end{array}$ & $\begin{array}{c}0.131 \\
(0.010)\end{array}$ & 7 & $\begin{array}{c}0.138 \\
(0.004)\end{array}$ & 6 & $\begin{array}{c}0.371 \\
(0.032)\end{array}$ & 9 \\
\hline $\begin{array}{l}\text { 3. Former } \\
\text { Yugoslavia }\end{array}$ & $\begin{array}{c}0.180 \\
(0.025)\end{array}$ & $\begin{array}{c}0.124 \\
(0.019)\end{array}$ & 13 & $\begin{array}{c}0.091 \\
(0.009)\end{array}$ & 15 & $\begin{array}{c}0.199 \\
(0.101)\end{array}$ & 16 \\
\hline 4. Greece & $\begin{array}{c}0.170 \\
(0.040)\end{array}$ & $\begin{array}{c}0.182 \\
(0.042)\end{array}$ & 14 & $\begin{array}{c}0.106 \\
(0.018)\end{array}$ & 12 & $\begin{array}{c}0.006 \\
(0.185)\end{array}$ & 20 \\
\hline 5. Italy & $\begin{array}{c}0.123 \\
(0.043)\end{array}$ & $\begin{array}{c}0.097 \\
(0.041)\end{array}$ & 16 & $\begin{array}{c}0.069 \\
(0.014)\end{array}$ & 18 & $\begin{array}{c}0.202 \\
(0.127)\end{array}$ & 15 \\
\hline 6. Turkey & $\begin{array}{c}0.100 \\
(0.074)\end{array}$ & $\begin{array}{c}0.082 \\
(0.044)\end{array}$ & 19 & $\begin{array}{c}0.047 \\
(0.032)\end{array}$ & 19 & $\begin{array}{c}0.820 \\
(0.321)\end{array}$ & 1 \\
\hline 7. Baltic States & $\begin{array}{c}0.248 \\
(0.023)\end{array}$ & $\begin{array}{c}0.157 \\
(0.018)\end{array}$ & 4 & $\begin{array}{c}0.158 \\
(0.009)\end{array}$ & 4 & $\begin{array}{c}0.423 \\
(0.057)\end{array}$ & 5 \\
\hline $\begin{array}{l}\text { 8. Former Soviet } \\
\text { Union }\end{array}$ & $\begin{array}{c}0.163 \\
(0.045)\end{array}$ & $\begin{array}{l}0.016 \\
(0.037)\end{array}$ & 15 & $\begin{array}{c}0.089 \\
(0.016)\end{array}$ & 16 & $\begin{array}{c}0.190 \\
(0.164)\end{array}$ & 17 \\
\hline 9. Czechoslovakia & $\begin{array}{c}0.184 \\
(0.043)\end{array}$ & $\begin{array}{c}0.238 \\
(0.032)\end{array}$ & 11 & $\begin{array}{c}0.115 \\
(0.017)\end{array}$ & 11 & $\begin{array}{c}0.252 \\
(0.087)\end{array}$ & 13 \\
\hline 10. Hungary & $\begin{array}{c}0.247 \\
(0.028)\end{array}$ & $\begin{array}{c}0.170 \\
(0.023)\end{array}$ & 5 & $\begin{array}{c}0.150 \\
(0.011)\end{array}$ & 5 & $\begin{array}{c}0.529 \\
(0.071)\end{array}$ & 2 \\
\hline 11. Poland & $\begin{array}{c}0.189 \\
(0.046)\end{array}$ & $\begin{array}{c}0.149 \\
(0.031)\end{array}$ & 10 & $\begin{array}{c}0.120 \\
(0.017)\end{array}$ & 10 & $\begin{array}{c}0.356 \\
(0.136)\end{array}$ & 10 \\
\hline 12. Germany & $\begin{array}{c}0.201 \\
(0.016)\end{array}$ & $\begin{array}{c}0.149 \\
(0.013)\end{array}$ & 8 & $\begin{array}{c}0.135 \\
(0.007)\end{array}$ & 8 & $\begin{array}{c}0.413 \\
(0.049)\end{array}$ & 6 \\
\hline 13. France & $\begin{array}{l}0.272 \\
(0.064)\end{array}$ & $\begin{array}{l}0.116 \\
(0.056)\end{array}$ & 1 & $\begin{array}{c}0.201 \\
(0.029)\end{array}$ & 1 & $\begin{array}{c}0.496 \\
(0.156)\end{array}$ & 3 \\
\hline 14. United Kingdom & $\begin{array}{l}0.110 \\
(0.051)\end{array}$ & $\begin{array}{l}0.077 \\
(0.039)\end{array}$ & 18 & $\begin{array}{c}0.071 \\
(0.023)\end{array}$ & 17 & $\begin{array}{c}0.213 \\
(0.125)\end{array}$ & 14 \\
\hline 15. The Netherlands & $\begin{array}{c}0.223 \\
(0.053)\end{array}$ & $\begin{array}{c}0.158 \\
(0.037)\end{array}$ & 6 & $\begin{array}{c}0.135 \\
(0.019)\end{array}$ & 7 & $\begin{array}{c}0.486 \\
(0.150)\end{array}$ & 4 \\
\hline 16. The Middle East & $\begin{array}{c}0.064 \\
(0.073)\end{array}$ & $\begin{array}{c}0.217 \\
(0.075)\end{array}$ & 20 & $\begin{array}{c}0.038 \\
(0.039)\end{array}$ & 20 & $\begin{array}{c}0.184 \\
(0.272)\end{array}$ & 18 \\
\hline 17. Africa & $\begin{array}{c}0.121 \\
(0.061)\end{array}$ & $\begin{array}{c}0.192 \\
(0.053)\end{array}$ & 17 & $\begin{array}{c}0.092 \\
(0.027)\end{array}$ & 14 & $\begin{array}{c}0.167 \\
(0.132)\end{array}$ & 19 \\
\hline 18. Asia & $\begin{array}{l}0.201 \\
(0.064)\end{array}$ & $\begin{array}{c}0.174 \\
(0.052)\end{array}$ & 8 & $\begin{array}{c}0.130 \\
(0.025)\end{array}$ & 9 & $\begin{array}{c}0.342 \\
(0.172)\end{array}$ & 12 \\
\hline 19. Latin America & $\begin{array}{c}0.251 \\
(0.086)\end{array}$ & $\begin{array}{c}0.083 \\
(0.082)\end{array}$ & 3 & $\begin{array}{c}0.189 \\
(0.039)\end{array}$ & 2 & $\begin{array}{c}0.372 \\
(0.146)\end{array}$ & 8 \\
\hline $\begin{array}{l}\text { 20. United States } \\
\text { and Canada }\end{array}$ & $\begin{array}{c}0.254 \\
(0.031) \\
\end{array}$ & $\begin{array}{c}0.183 \\
(0.027) \\
\end{array}$ & 2 & $\begin{array}{c}0.188 \\
(0.014) \\
\end{array}$ & 3 & $\begin{array}{c}0.391 \\
(0.076) \\
\end{array}$ & 7 \\
\hline All natives & & $\begin{array}{c}0.140 \\
(0.004)\end{array}$ & & $\begin{array}{c}0.090 \\
(0.002)\end{array}$ & & $\begin{array}{c}0.222 \\
(0.013)\end{array}$ & \\
\hline All immigrants & $\begin{array}{c}0.207 \\
(0.005)\end{array}$ & & & $\begin{array}{c}0.129 \\
(0.002)\end{array}$ & & $\begin{array}{c}0.386 \\
(0.016)\end{array}$ & \\
\hline $\begin{array}{l}\text { Weighted average of } \\
\text { mobility within } \\
\text { immigrant groups }\end{array}$ & $\begin{array}{c}0.196 \\
(0.005)\end{array}$ & & & $\begin{array}{c}0.121 \\
(0.002)\end{array}$ & & $\begin{array}{c}0.351 \\
(0.017)\end{array}$ & \\
\hline
\end{tabular}


Table 6 (continued). Estimates of within pooled immigrants group and native comparison group intergenerational earnings mobility. (Standard errors within parentheses).

\begin{tabular}{|c|c|c|c|c|c|c|c|}
\hline $\begin{array}{l}\text { Geographic } \\
\text { origin }\end{array}$ & $\begin{array}{l}\text { Regression } \\
\text { estimates. } \\
\text { Second } \\
\text { generation } \\
\text { immigrants }\end{array}$ & $\begin{array}{l}\text { Regression } \\
\text { estimates. } \\
\text { Native } \\
\text { comparison } \\
\text { group }\end{array}$ & $\begin{array}{c}\text { Rank. } \\
\text { Second } \\
\text { generation } \\
\text { immigrants }\end{array}$ & $\begin{array}{l}\text { Correlation } \\
\text { coefficient. } \\
\text { Second } \\
\text { generation } \\
\text { immigrants }\end{array}$ & $\begin{array}{l}\text { Rank. } \\
\text { Second } \\
\text { generation } \\
\text { immigrants }\end{array}$ & $\begin{array}{c}\text { IV. } \\
\text { Second } \\
\text { generation } \\
\text { immigrants }\end{array}$ & $\begin{array}{l}\text { Rank. } \\
\text { Second } \\
\text { generation } \\
\text { immigrants }\end{array}$ \\
\hline $\begin{array}{l}\text { 1. Nordic } \\
\text { countries }\end{array}$ & $\begin{array}{c}0.192 \\
(0.007)\end{array}$ & $\begin{array}{c}0.128 \\
(0.006)\end{array}$ & 4 & $\begin{array}{c}0.116 \\
(0.003)\end{array}$ & 4 & $\begin{array}{c}0.346 \\
(0.021)\end{array}$ & 3 \\
\hline $\begin{array}{l}\text { 2. Southern } \\
\text { Europe and } \\
\text { Turkey }\end{array}$ & $\begin{array}{c}0.146 \\
(0.028)\end{array}$ & $\begin{array}{c}0.124 \\
(0.026)\end{array}$ & 5 & $\begin{array}{c}0.085 \\
(0.012)\end{array}$ & 5 & $\begin{array}{c}0.264 \\
(0.103)\end{array}$ & 5 \\
\hline $\begin{array}{l}\text { 3. Eastern } \\
\text { Europe }\end{array}$ & $\begin{array}{c}0.226 \\
(0.012)\end{array}$ & $\begin{array}{c}0.158 \\
(0.010)\end{array}$ & 1 & $\begin{array}{c}0.138 \\
(0.005)\end{array}$ & 3 & $\begin{array}{c}0.395 \\
(0.034)\end{array}$ & 2 \\
\hline $\begin{array}{l}\text { 4. Western } \\
\text { Europe, US } \\
\text { and Canada }\end{array}$ & $\begin{array}{c}0.209 \\
(0.013)\end{array}$ & $\begin{array}{c}0.150 \\
(0.010)\end{array}$ & 3 & $\begin{array}{c}0.143 \\
(0.006)\end{array}$ & 2 & $\begin{array}{c}0.398 \\
(0.037)\end{array}$ & 1 \\
\hline $\begin{array}{l}\text { 5. Africa } \\
\text { and the } \\
\text { Middle East }\end{array}$ & $\begin{array}{c}0.086 \\
(0.046)\end{array}$ & $\begin{array}{c}0.193 \\
(0.044)\end{array}$ & 6 & $\begin{array}{c}0.064 \\
(0.024)\end{array}$ & 6 & $\begin{array}{c}0.137 \\
(0.127)\end{array}$ & 6 \\
\hline $\begin{array}{l}\text { 6. Latin } \\
\text { America } \\
\text { and Asia }\end{array}$ & $\begin{array}{c}0.222 \\
(0.051)\end{array}$ & $\begin{array}{c}0.144 \\
(0.045)\end{array}$ & 2 & $\begin{array}{c}0.154 \\
(0.022)\end{array}$ & 1 & $\begin{array}{c}0.274 \\
(0.124)\end{array}$ & 4 \\
\hline
\end{tabular}

An apparent feature of the results obtained above is that the groups where we observed the highest degree of intergenerational earnings mobility (groups originating from Africa, Middle East and Southern Europe) also have the lowest level of earnings in the first generation. It is quite conceivable that the low level of intergenerational transmission of human capital within these groups can simply be explained by their having a low level of skills in the first generation, rather than by ethnic differences. To discriminate between these two hypotheses, we estimate a model allowing for heterogeneous intergenerational earnings mobility in different earnings levels in the first generation. This model is specified as

$$
y_{s i}=a+r_{1} y_{f i}+\sum_{k=2}^{6} b_{k} I_{k}+\sum_{k=2}^{6} r_{k} I_{k} * y_{f i}+\sum_{j=2}^{5} g_{j} Q_{j} * y_{s i}+f\left(A g e_{f i}\right)+g\left(A g e_{s i}\right)+u_{i} \text {, }
$$

where $I_{k}$ is a set of dummy variables indicating the five different regions of origin and $Q_{j}$ is a set of dummy variables for a quintile of the earnings distribution of first generation earnings. The model also includes a quadratic specification in both first and second-generation age as well as, for specification (2) and (4), a full set of interactions between the age variables and the group of immigrant dummy variables. 
Table 7. Intergenerational earnings mobility in different earnings levels in the first generation.

\begin{tabular}{|c|c|c|c|c|}
\hline \multirow[t]{2}{*}{ Variable } & \multicolumn{2}{|c|}{ Immigrants } & \multicolumn{2}{|c|}{ Natives } \\
\hline & (1) & (2) & (3) & (4) \\
\hline \multirow{2}{*}{$\overline{y_{f}}$} & 0.145 & 0.133 & 0.084 & 0.075 \\
\hline & $(0.013)$ & $(0.014)$ & $(0.011)$ & $(0.012)$ \\
\hline \multirow{2}{*}{$Q_{2} * y_{f}$} & -0.001 & -0.001 & -0.000 & -0.000 \\
\hline & $(0.001)$ & $(0.001)$ & $(0.001)$ & $(0.001)$ \\
\hline \multirow{2}{*}{$Q_{3} * y_{f}$} & -0.000 & 0.000 & 0.000 & 0.000 \\
\hline & $(0.001)$ & $(0.001)$ & $(0.001)$ & $(0.001)$ \\
\hline \multirow{2}{*}{$Q_{4} * y_{f}$} & 0.001 & 0.001 & 0.001 & 0.001 \\
\hline & $(0.001)$ & $(0.001)$ & $(0.001)$ & (0.001) \\
\hline \multirow{2}{*}{$Q_{5} * y_{f}$} & 0.005 & 0.005 & 0.005 & 0.005 \\
\hline & $(0.001)$ & $(0.001)$ & $(0.001)$ & $(0.001)$ \\
\hline$I_{2} * y_{f}$ & - & $\begin{array}{c}-0.035 \\
(0.029)\end{array}$ & - & $\begin{array}{c}-0.003 \\
(0.026)\end{array}$ \\
\hline$I_{3} * y_{f}$ & - & $\begin{array}{c}0.031 \\
(0.014)\end{array}$ & - & $\begin{array}{c}0.025 \\
(0.011)\end{array}$ \\
\hline$I_{4} * y_{f}$ & - & $\begin{array}{c}0.013 \\
(0.015)\end{array}$ & - & $\begin{array}{c}0.020 \\
(0.012)\end{array}$ \\
\hline$I_{5} * y_{f}$ & - & $\begin{array}{c}-0.095 \\
(0.046)\end{array}$ & - & $\begin{array}{c}0.055 \\
(0.045)\end{array}$ \\
\hline$I_{6} * y_{f}$ & - & $\begin{array}{c}0.028 \\
(0.052)\end{array}$ & - & $\begin{array}{c}0.009 \\
(0.044)\end{array}$ \\
\hline $\begin{array}{l}\text { Test for joint } \\
\text { significance } \\
\text { parameters of } \\
\mathrm{I}_{2} * \mathrm{y}_{\mathrm{f}}-\mathrm{I}_{6} * \mathrm{y}_{\mathrm{f}} \\
\text { (p-value) }\end{array}$ & - & 0.028 & - & 0.196 \\
\hline $\mathrm{R}^{2}$ & 0.094 & 0.099 & 0.030 & 0.038 \\
\hline $\mathrm{N} * \mathrm{t}$ & & & & \\
\hline
\end{tabular}

The results from the estimation of the model are presented in Table 7. The first two columns show the result for immigrants and the last two columns the corresponding ones for the comparison group of natives. The results shown in column (1) and (3) correspond to the model with homogenous intergenerational mobility within ethnic groups, but heterogeneous mobility within income groups. These results show a very similar pattern. There is significantly lower mobility in the group with the highest first generation income. However, the magnitude of the difference is very small.

Columns (2) and (4) show the results from the full models, i.e., when mobility is also allowed to be heterogeneous within ethnic groups. The result from the F-test of joint significance of the interaction terms between first-generation and the ethnic group indicators shows that homogenous mobility within different groups can be rejected. Once more, homogeneity within the native comparison groups cannot be rejected. Altogether, we conclude from these 
results that heterogeneous mobility between groups with different initial skills does not seem to be important enough to account for the observed differences in intergenerational mobility between the ethnic groups.

\subsection{Determinants of between-group intergenerational mobility}

In Section 2, we concluded that the initial level of human capital, i.e., the human capital level in the first generation and its transmission to the next generation are of importance for the success of second-generation immigrants on the labor market in the new country. In this section, we will empirically examine the importance of these factors for the average relative earnings of different groups of second-generation immigrants.

We use two different measures of the average human capital level in the first generation: the average relative earnings from labor of the first generation and the level of GDP per capita in the country of origin. To measure the transition of human capital between generations, we use the results obtained from intergenerational correlation in labor earnings. Table 8 shows the results from regressions where we use the relative income level of the second-generation immigrant group as a dependent variable and different permutations of the three variables explained above as independent variables.

Table 8. Determinants of average relative earnings of different groups of second-generation immigrants (t-values within parentheses).

\begin{tabular}{lcccc}
\hline Variable & $(1)$ & $(2)$ & $(3)$ & $(4)$ \\
\hline Intercept & 0.074 & -0.110 & -1.059 & -0.192 \\
& $(1.88)$ & $(-1.37)$ & $(-3.39)$ & $(-0.66)$ \\
Log per capita GDP & - & - & 0.239 & 0.002 \\
& & & $(3.13)$ & $(0.29)$ \\
Intergenerational & - & 1.373 & - & 1.356 \\
correlation & & $(2.56)$ & & $(2.63)$ \\
First generation & 1.425 & 1.190 & - & 1.340 \\
income & $(4.47)$ & $(4.05)$ & & $(3.69)$ \\
$\mathrm{R}^{2}$ & 52.6 & 65.7 & 45.0 & 81.6 \\
$\mathrm{~N}$ & 20 & 20 & 14 & 14 \\
\hline
\end{tabular}

Note: Specifications (3) and (4) omit former Yugoslavia, the Baltic States, the Soviet Union, Czechoslovakia, Hungary and Poland since per capita GDP was not available for these countries. The GDP variable gives the (log) per capita GDP in the source country in 1970. 
Per capita GDP in the fathers' home countries is used in specification (3) in Table 8. This time, the level of the coefficient has no firm interpretation; however, the fact that it is positive and significantly different from zero on the five percent level shows the level of economic development in the source country to have a lasting effect in the second generation.

Specification (2) shows the result when the within-group intergenerational correlation is included as an explanatory variable. This result confirms the pattern observed in Section 5.2 that groups with low intergenerational income mobility, or a high degree of intergenerational transmission of human capital, tend to have higher earnings in the second generation. In specification (4), we have also added GDP per capita in the country of origin and the average relative income level of the first generation to the specifications. As can be seen in Table 8, the significance of the within-group intergenerational correlation in earnings is also maintained in this specification.

\section{Conclusions}

Two main conclusions emerged from this study. The first - which has strong relevance for the Swedish development, but less general relevance as compared to the second conclusion - is the overall convergence between natives and immigrants, hiding a divergence between groups with different ethnic origins among immigrants. The first part of this conclusion, the overall convergence, is much in line with previous research on both Swedish and US data. Österberg (2000) shows, on different data than used in this study, that the earnings differential between immigrants and natives in Sweden is smaller in the second generation than in the first. On data from the US, Borjas (1993) concludes that children of immigrants earn more than natives, although their parents had an even larger earnings advantage as compared to natives.

The second part of the first conclusion, the earnings divergence between different immigrant groups, is strikingly different from results obtained on US data. Borjas (1993) finds a strong average convergence between groups of different ethnic origins on the US labor market. Our results show that groups that have subsequently been more important in the immigrant cohorts arriving after 1970 - in particular, those originating from Africa and the Middle East - further deteriorate their average position in the second generation. Our result indicates that the 
current problem of assimilation of these ethnic groups on the labor market may last, and accentuate, over the next generation.

The second main conclusion is that intergenerational earnings mobility is lower among immigrants than among natives. The result that this is true also for the weighted average for all measures of earnings mobility within each group is of particular importance. This implies that Borjas' (1992) model with ethnic factors is not a sufficient explanation for why immigrants tend to have lower earnings mobility across generations. The result suggests that the family is more important in the intergenerational transmission of human capital for immigrants. This is not surprising, given that immigrants are likely to have more restricted access to the society outside the family - such as educational systems and social networks

We also find that the overall lower rate of earnings mobility among immigrants hides significant heterogeneity between different immigrant groups. This result indicates that different immigrant groups are not equally successful in transmitting human capital between generations. Finally, we find that groups with a low degree of earnings mobility - i.e., those who are successful in transmitting human capital - on average improve their position on the labor market in the second generation more. This result strengthens the interpretation that differences in earnings mobility between different groups are driven by differences in the transmission of human capital over generations between groups.

\section{References}

Becker, G. S. and N. Tomes, (1986) "Human Capital and the Rise and Fall of Families", Journal of Labor Economics, 4, 1-39.

Björklund, A. and L. Chadwick (2003) "Intergenerational income mobility in permanent and separated families", Economics Letters, 80, 239-246.

Björklund, A. and M. Jäntti, (1997) "Intergenerational Income Mobility in Sweden Compared to the United States", American Economic Review, 87, 1009-1018.

Böhlmark, A. and M. Lindquist (2005) "Life-Cycle Variation in the Association between Current and Lifetime Income: Country, Gender and Cohort Differences". Swedish Institute for Social Research, Working Paper 4/2005.

Borjas, G. J. (1992) "Ethnic Capital and Intergenerational Mobility", Quarterly Journal of Economics, 107, 123-150. 
Borjas, G. J. (1993) “The Intergenerational Mobility of Immigrants”, Journal of Labor Economics, 11, 113-134.

Borjas, G.J. (1994) “The Economics of Immigration”, Journal of Economic Literature, 32, 1667-1717.

Haider, S. and G. Solon (2005) "Life-Cycle Variation in the Association between Current and Lifetime Earnings", forthcoming American Economic Review.

Moulton, B. (1986) "Random Group Effects and the Precision of Regression Estimates", Journal of Econometrics, 3, 385-397.

Österberg, T. (2000) Economic Perspectives on Immigrants and Intergenerational Transmissions. Dissertation, Department of Economics, Gothenburg University.

Rooth, D.-O. and J. Ekberg (2003) "Unemployment and Earnings for Second Generation Immigrants in Sweden. Ethnic background and parent composition", Journal of Population Economics, 16, 787-814.

Solon, G. (1992) "Intergenerational Income mobility in the United States", American Economic Review, 82, 393-408.

Solon, G. (1999) "Intergenerational Mobility in the Labor Market", in D. Card and O. Ashenfelter (eds.), Handbook of Labor Economics, vol 3A, North-Holland.

Zimmerman, K. (ed., 2005) European Migration, Oxford University Press: Oxford. 